\title{
Milk Biodiversity: Future Perspectives of Milk and Dairy Products from Autochthonous Dairy Cows Reared in Northern Italy
}

\author{
Ricardo Communod ${ }^{1}$, Massimo Faustini ${ }^{1}$, \\ Luca Maria Chiesa', Maria Luisa Torre², \\ Mario Lazzati ${ }^{3}$ and Daniele Vigo ${ }^{1}$ \\ ${ }^{1}$ Department of Veterinary Sciences and Technologies for Food Safety, \\ Faculty of Veterinary Medicine, University of Milan, \\ ${ }^{2}$ Department of Drug Sciences, \\ Faculty of Pharmacy, University of Pavia \\ ${ }^{3}$ Pavia Breeders Association Director, \\ Italy
}

\section{Introduction}

The United Nations is alerting worldwide population: our planet will undergo a drastic change in less than 40 years. Human population will increase to reach 9 billion inhabitants; consequently, cereal annual production should increase to be about 3 billion tons compared to current 2.1tons. According to a Food and Agriculture Organization's report FAO, "FAO 2050", human birthrate is expected to prevail in developing countries. Thus, food resources, such as wheat, corn, barley, and others, will be used to ensure people survival in these countries, which will reduce availability of silage and concentrates addressed to cattle breeding. This redistribution of primary resources will force bovine species to a diet based on forage biomass with low energy and water consumption, associated with the use of less productive areas such as foothills, forests and pastures, thus implementing availability of cereals for human consumption. Noticeably, climate changes will persist and modify any environment where plants grow. In this context, farmers and breeders will be faced with new challenges. Maintaining genetic biodiversity in plants including some wild peculiarities may help to solve some of current agricultural problems and protecting such biodiversity appear therefore crucial to increase a sustainable and efficient use of land. According to 'Europe 2020' protocol established by United Nations, greenhouse gas emissions must be reduced by $20 \%$, energy efficiency increased by $20 \%$ with a reduction in consumption, and energy from renewable sources pushed up by $20 \%$. Therefore, it is expected that in certain areas long-term and perennial crops will be implemented; energy consumption for sowing, harvesting, and drying products for livestock consumption will be reduced; availability of mature manure to improve soil fertilization, reducing easily washable nitrogen, will be increased. In the coming decades, an actually thorny scenario will affect future generations: processes such as steady population and consumption growth will cause a reduction in the response capacity of ecosystems, and a consequent decrease in food resources, water and 
energy. The agricultural system is strictly implied in the abovementioned issues, and plays its role as a multifaceted character. In fact, agriculture can give answers to the drawing demand for food while consuming huge quantities of water and fuels on the planet to achieve its goals. To date, care for biodiversity is pivotal to improve and increase a sustainable and efficient use of land.

\section{Dairy cattle breeding: European and Italian scenarios}

In parallel with vegetal selection aimed to maximize production, even farm animal biodiversity has been damaged to select animals with fast food conversion into milk and meat. This mono-aptitude selective criterion has caused a decline in several sectors, the main ones being reproductive performances and quality of products (Schennink et al., 2007), problems easily noticed in the dairy cattle scenario. In fact, mainly in Friesian breeds, reproductive performances have decreased worldwide, with negative consequences to cows robustness and longevity by increasing stress, udder health disturbances and locomotion disorders (Roxström et al., 2001a). Holstein, Brown Swiss and Jersey, subjected to a monoaptitude selection in the last 40 years, almost aimed to a quantitative milk production, reach, from a physiological point of view, a very critical situation: they have missed good reproductive efficiency characters, (e.g. calving interval and conception rate (Sørensen et al., 2007), excellent longevity in farm, resistance to stress and diseases (metabolic syndrome, ketosis, mastitis and foot diseases)( Roxström et al., 2001a; Roxström et al., 2001b; Carlén, 2004)), whereas they have dramatically increased "energy and financial voracity" (diet based on starch and protein meals, great health and structural investments due to several high recurring diseases (Ingvartsen et al., 2003; Collard et al., 2000; Carlén et al., 2004).

Italian dairy breeding has followed the European trend, by selecting high yielding Holstein cows, influencing some important milk quality parameters, such as milk fat, protein and somatic cell count, all involved in cheese making processes. Recently, Italian researchers have demonstrated that milk with a somatic cell content greater than 400,000 cells/ml evidences a scarce aptitude to rennet coagulation and, in general, it does not seem to be suitable for cheese production, with particular reference to Grana cheese production (Sandri et al., 2010). Italy is the most important cheese producer and exporter in Europe, with its about 460,000 tons of products and almost 3 billion Euros (data from www.clal.it, www.ismea.it) derived from PDO (Protected Designation Origin) and PGI (Protected Geographical Indication). The most representative Italian products are certainly Parmigiano Reggiano and Grana Padano, which have recently increased by $9.8 \%$ their export trend to Germany, the United States, France, Switzerland and the United Kingdom. Therefore, both for the Italian breeding system and for the whole country it is very important to try to solve current problems related to health and welfare of their dairy cows, in order to maintain a unique cheese production and exportation.

An innovative idea lies in finding solutions to the current dairy breeding scenario by orienting our sight on the existing Italian bovine heritage, and diversifying from the current thought that has driven genetic selection of dairy cosmopolitan breeds in the last 40 years. Using very rustic and frugal cattle with double (milk and meat) or threefold (milk, meat and work) aptitude, such as Italian autochthonous cows, showing a good food conversion into milk and meat, would be highly advantageous, compared with the more cosmopolitan and 
selected Holstein, Brown Swiss and Jersey, unable to maintain high milk yield and reproduction standards, reared with a protein-deficient diet mainly based on forage and cereals.

\section{Autochthonous dairy cattle of northern Italy}

\subsection{Breed: Origin, diffusion, traits, aptitude - Cabannina (Bigi and Zanon, 2008)}

These cows are native to the province of Genoa and are reared in Liguria region and in Pavia province in Lombardy; currently, about 220 heads are enrolled in the population register. They have a dark brown coat with light-colored lines and reddish shades. The head is small, short, light; the muzzle is black and widely white-bordered. The reduced size (withers height of $122 \mathrm{~cm}$ for females and $134 \mathrm{~cm}$ for males, with a maximum adult live weight of 4.5 quintals), short and powerful limbs, and very hard claws, make these animals excellent to grazing, the only animals able to effectively use plant resources in the high slopes of the Ligurian Apennines. The Cabannina Breeding, based on local grazing for a large part of the year, determines the specific characteristics of flavor and authenticity of the final products, milk and cheese. For this reason, it can be said that Cabannina is the testimony for the province of Genoa to the indissoluble link between land and its products, and that it perfectly expresses the adaptation process of the characteristics of both breed and environment, where it has evolved and maintained over time. Milk production from this cow breed is kept on 20 to 30 quintals/year and its high longevity (it is common to find in farm cows aged over 12 years) confirms their excellent adaptation to their territory. Their cheese, entirely derived from raw milk, is called "U Cabanin" (The Cabanin). It was established in 2007 thanks to the intervention of the Breeders Association and the Chamber of Commerce of Genoa. From 2010, U Cabanin is one of Slow Food Presidia and according to Carlo Petrini, Slow Food Association founder and President, Cabannina cow breed represents a correct mix of pleasure for food and responsibility, sustainability and harmony with nature.



Fig. 3.1. Cabannina cow. 


\subsection{Breed: Origin, diffusion, traits, aptitude - Varzese-Ottonese-Tortonese (Bigi and Zanon, 2008)}

As clearly shown by its long compound name, this breed's area of origin includes the northern Italian Apennines and 4 neighbouring regions: Lombardy, Emilia Romagna, Liguria and Piedmont. Currently there are about 240 heads enrolled in the population register, atomized in few farms in Pavia, Piacenza, Alessandria and Milano provinces. The cows in this breed show a uniform reddish-blond coat, more or less intense, with limited lighter shades around their muzzles, eyes, bellies, inner thighs and distal limbs. Their medium size (withers height of $135 \mathrm{~cm}$ for females and $145 \mathrm{~cm}$ for males with a maximum adult live weight of 5.5 quintals ), and their distinct characteristics of rusticity, frugality, fertility and longevity (this breed can easily reach 10 births and the goal of one calf/year) make these animals be used as first choice in marginal areas like mountain, wood and foothill grazes. Born to be primarily used for work - in fact, bulls were famous for their strength, endurance, docility and for their resistant hoofs), and even cows were employed for rapid and light draft - this breed was then appreciated for the production of meat and milk, used to make excellent cheese today including some important cheese named "Nisso", "Robiola", "Montebore" and "Molana", all produced in Oltrepo regions, areas lying south of the River Po. The Varzese breed has been recently required by farms where tourists can be lodged and/or consume local products. In addition, it can be found in teaching farms and, as it recalls traditional aspects of the ancient rural world, it plays a role in folklore events.

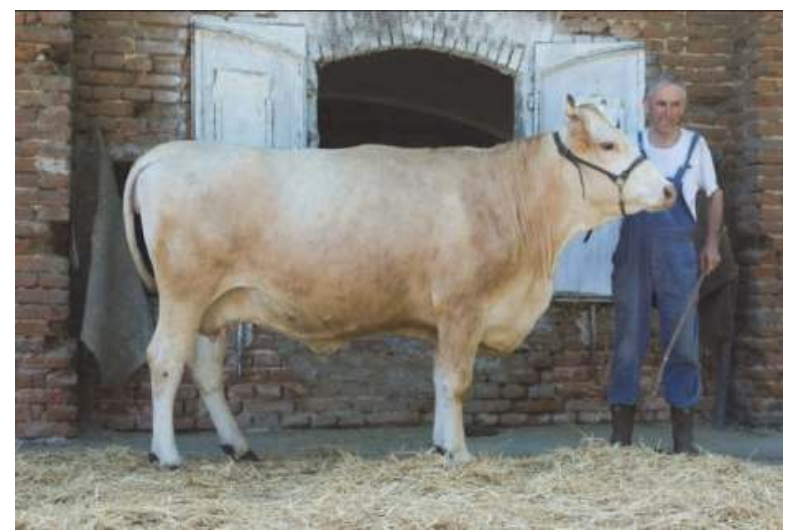

Fig. 3.2. Varzese cow

\section{Comparative study among breeds}

To understand to what extent the regulatory mechanisms of production and reproduction of high yielding dairy cows can be altered, comparative physiological studies within Italian dairy breeds experiencing no genetic improvement were necessary. This investigation aimed to increase scientific information about these animals in the perspective of developing a more efficient and sustainable dairy breeding. Data now available, provided by ongoing research at our laboratory, are actually encouraging. In our research, two endangered local bovine breeds of Northern Italy, Varzese and Cabannina, were considered and compared with Friesian cows in relation to some aspects characterizing lactation and reproduction. 


\subsection{Milk study: Milk fat, the most variable component}

Milk is one of the most complete foods in nature; its nutritional value is mainly attributable to proteins and fats, the latter being its most variable component. Milk fat is present as a suspension of defined globules showing a biological membrane giving each globules an identity as well as a precise structural and functional behavior. The globule dimensions range from 0.5 to $20 \mu \mathrm{m}$; they have been extensively described in mass milk of Holstein cows (Lopez, 2005), both as native and as subjected to treatments, i.e. homogenization and pasteurization (Michalski et al., 2003). The fat globules interact with milk caseins of curd and their size can influence the processes of lipolysis and ripening of cheese (Lopez, 2005; Michalski et al., 2004). Our research was oriented toward fat and fatty acid composition, important features in milk since they influence its physical, organoleptic and nutritional properties (Chilliard et al., 2000). Recent studies showed that milk composition is determined by several factors such as diet (Banks et al., 1983; Grummer, 1990; Perfield et al., 2006; Perfield et al., 2007), stage of lactation and season (Coulon, 1994), genetics and management (Schennink et al., 2007). Milk fat is characterized by high amounts of saturated fatty acids (SFA), especially myristic acid (C14:0) and palmitic acid (C16:0), and by a low amount of mono- and poly-unsaturated fatty acids (Soyeurt et al., 2006). Milk is the major contributor of SFA to human diet, a fact that led to a widespread conviction for which milk and dairy products can negatively affect human health. A recent meta-analysis conducted by Elwood et al. (2010) demonstrated a reduction in risk for several causes of death (ischaemic heart disease, stroke and incident diabetes) in subjects with the highest consumption of dairy products compared to those with the lowest intake. In order to understand lifestyle-related diseases, such as obesity, hyperlipidemia, arteriosclerosis, diabetes mellitus and hypertension, researchers oriented their attention to diet and in particular to dietary lipids (Vessby, 2003). The most studied milk components are $\omega-6$ and $\omega$ 3 poli-unsaturated fatty acids (PUFA), conjugated linoleic acids (CLA) and SFA, but to date also mono-unsaturated fatty acids (MUFA) should be considered as confering important nutritional quality to milk. Not only could MUFA profile be interesting, but also $\Delta 9$ desaturase activity since it is the key enzyme to convert SFA in MUFA and to control conjugated linoleic acids concentration. Some researchers (Schennink et al., 2007; Soyeurt et al., 2007) estimated that a moderate heritability of this enzyme and the concentration of MUFA have another chance to improve unsaturated fatty acids (UFA) in milk composition. In mammary glands, $\Delta 9$-desaturase catalyzes the insertion of a double bond between carbon atoms 9 and 10 of fatty acid (Pereira et al., 2003). In mammary glands, fatty acids originating from blood or from de novo fatty acid synthesis can be desaturated and the degree of unsaturation is often calculated by a so-called "desaturase index".

\subsection{Reproduction study: Uterine involution monitored by a new non invasive method}

Fertility is a complex parameter undoubtedly influenced by genetics, environment and management. These components exist and act in synergy and simultaneously, making it extremely difficult for any strategies and technologies applied to set up a stabilization of reproductive efficiency. The post-partum period has a basic effect on the resumption of ovarian cyclicity and future reproductive efficiency, a parameter that unequivocally determines the career of a cow in the herd. By definition, the postpartum period is, , a physiological process between birth and complete uterine involution, essential to bring the 
female genital apparatus back to favorable conditions for optimal embryonic development and implantation (Badinand 1993; Kaidi et al., 1991b). Immediately after birth a cow uterus weighs about $10 \mathrm{~kg}$ and in a month it reaches a weight of $1 \mathrm{~kg}$ physiologically (Badinand 1993). Its involution can be appreciated clinically by transrectal palpation: under normal conditions a uterus can be completely taken in a hand after 2-3 weeks and never before 1012 days after birth (Badinand 1993). Uterine involution in cattle can be affected by many factors, such as dystocia, uterine prolapse, abortion and bacterial infections ( $93 \%$ of uteri in cattle can be infected by a large amount of bacteria until 15 days post-partum) (Elliot et al., 1968). Uterine involution is characterized by a significant tissue remodeling: measuring cellular turnover markers, such as hydroxyproline (HYPRO), the most abundant amino acid present in uterine collagen, could provide useful information on involution progress. The serum concentration of this protein increases gradually in late gestation and it is related to the mechanism of placental separation and uterine involution (Kaidi et al., 1991a).

\section{Materials and methods to describe milk production}

A total number of 13 lactating cows were enrolled. Two local breeds were taken into account (Varzese, $\mathrm{n}=4$ and Cabannina, $\mathrm{n}=4$ ) and compared with a cosmopolite breed (Friesian, $\mathrm{n}=5$ ). All animals were raised in the same center located in Northern Italy and fed with the same diet. Milk samples from the whole udder were collected during morning milking and from a lactometer. Samples, kept at $4^{\circ} \mathrm{C}$, were forwarded to a laboratory and analyzed within 2 hours. The animals considered were in early and mid lactation, ranging from 40 to 180 days, and the intervals of collection were at 20 days. The starting point of milk collection was chosen in order to assure the full physiological uterine involution in all heads.

\subsection{Milk fat globule granulometry}

Distributions of fat globules diameters were performed using a granulometer laser scatter, according to the method proposed by Lopez, 2005. Size distributions were characterized by volume weighted diameter of the globules $\left(\mathrm{d}_{43}\right.$, in microns) and by specific surface area (SSA, in $\mathrm{cm}^{2}{ }^{*} \mathrm{ml}^{-1}$ ). Data obtained were subjected to analysis of covariance (ANCOVA, GLM procedure, SPSS ver. 17.0 per Windows); breed was taken into account as a fixed factor, and day of lactation as a covariate. The differences between breeds were evaluated by LSD (least significant difference) for multiple comparisons. To assess the evolution of globular diameter (expressed as $\mathrm{d}_{43}$ ) in relation to the days of lactation the following relationship was applied :

$$
\mathrm{D}_{43}=\left(\mathrm{A}+\mathrm{B}^{*}(\text { days of lactation })\right) /\left(1+\mathrm{C}^{*}(\text { days of lactation })\right)
$$

where A, B, C are constants.

\subsection{Milk fat content, fatty acid extraction, derivatization and desaturase indices}

The determination of milk fat content was performed by a UV Spectrophotometric method, according to Forcato et al. (2005). Lipids extraction was performed according to a modified Bligh \& Dyer method (Manirakiza et al., 2001) and derivatization according to MoltoPuigmartì et al. (2007). Fatty acids were identified using external standards (Standard 
containing 37 fatty acids, FAME Mix 37, Supelco, USA) and two CLA standards (Matreya, USA), and quantified using 19:0 (nonadienoic acid) as internal standard. Peak areas were corrected according to the theoretical relative FID response correction factors (TRFs) published by Ackman (2002). Results are presented as $\mathrm{g} / 100 \mathrm{~g}$ fatty acids (\% by weight). Percentage of the single contribute of each fatty acid was calculated on the total of the area under known peaks. Percentages of myristoleic acid (C14:1-cis-9), palmitoleic acid (C16:1-cis9) and oleic acid (C18:1-cis-9) were taken into account. Desaturase indices ( $\Delta$ ) were calculated according to Schennink et al. (2008) and total desaturase index (TDI) was calculated according to Mele et al. (2007) on C14, C16 and C18 fatty acids; briefly, the individual $\Delta$ was calculated as $C x: 1 /(C x+C x: 1)^{\star} 100$, where $x$ is the number of carbons of fatty acid. The total desaturase index was calculated as

$\left(\mathrm{C} 14: 1+\mathrm{C} 16: 1+\mathrm{C} 18: 1 /(\mathrm{C} 14+\mathrm{C} 14: 1+\mathrm{C} 16+\mathrm{C} 16: 1+\mathrm{C} 18+\mathrm{C} 18: 1)^{*} 100\right.$.

\subsection{Statistical analysis}

All data were analyzed by $\mathrm{JMP}^{\circledR}$ software ver. 7.0.2 (SAS Institute Inc.) for Windows platform.

\section{Materials and methods to describe reproduction}

A total number of 16 lactating cows were enrolled. All animals were multiparous, with eutocic stillbirth, normal post-partum period and raised in the same center located in Valle Salimbene (Pavia) in Northern Italy. All animals were followed for the first 30 days after birth and were divided into 3 treatment groups based on breed, specifically:

- 4 Varzese cows (VAR group);

- 5 Cabannina cows (CAB group);

- 7 Friesian cows (FRI group);

All cows did not undergo any gynecological clinic examination as manipulation (palpation and retraction of uterus in the pelvic cavity could produce stimuli influencing a physiological uterine involution) (Rosemberger, 1979). In this regard Hurtgen and Ganiam (1979), in a trial conducted on mares, showed that intracervical or intrauterine manipulation during the luteal phase of the estrous cycle may directly or indirectly stimulate release of endogenous prostaglandins that trigger regression of the corpus luteum, followed by oestrus onset and ovulation (Hurtgen and Ganiam (1979). In our trial animals that showed persistent hyperthermia $\left(40.5{ }^{\circ} \mathrm{C}\right)$ for over 48 hours, or post-partum syndromes requiring drug administration that could affect uterine involution (e.g., administration of boron gluconate drugs, steroidal and non steroidal anti-inflammatory drugs) were excluded.

\subsection{Serum hydroxyproline determination}

From the coccygeal vein of each subject a single operator collected blood samples without anticoagulant additives in order to obtain serum. Sampling was performed on days 0 (day of birth),1,2,3,4,5,10,15,20,25,30 post-partum and hydroxyproline content was analyzed by a spectrophotometric method as reported by Huszar et al. (1980). 


\subsection{Statistical analysis}

All data were analyzed by JMP ${ }^{\circledR}$ software ver. 7.0.2 (SAS Institute Inc.) for Windows platform.

\section{Results}

\subsection{Milk fat globules}

Dimensional analysis of milk fat globules highlighted deep differences among breeds, mainly between Friesian and the others. Friesian cows are characterized by larger milk fat globules (Fig. 7.1., p <0.05) and by a significantly lower specific surface area (Fig. 7.2., $\mathrm{p}$ $<0.05$ ). Cabannina breed shows the smallest fat globules (Fig. 7.1., p <0.05) and the highest specific surface area (Fig. 7.2., p <0.05). Varzese breed occupies an intermediate position (Figs. 7.1. and 7.2., $\mathrm{p}<0.05$ ). In all breeds, globule diameter trend decreases during lactation. This reduction is more evident in the first weeks of lactation and slows down until it reaches a plateau in the following months. These features can elucidate some physiological functions of fat globules on mammalian offspring and on industrial transformation of milk from niche breeds. Key data from our research are collected and presented in the following figures:
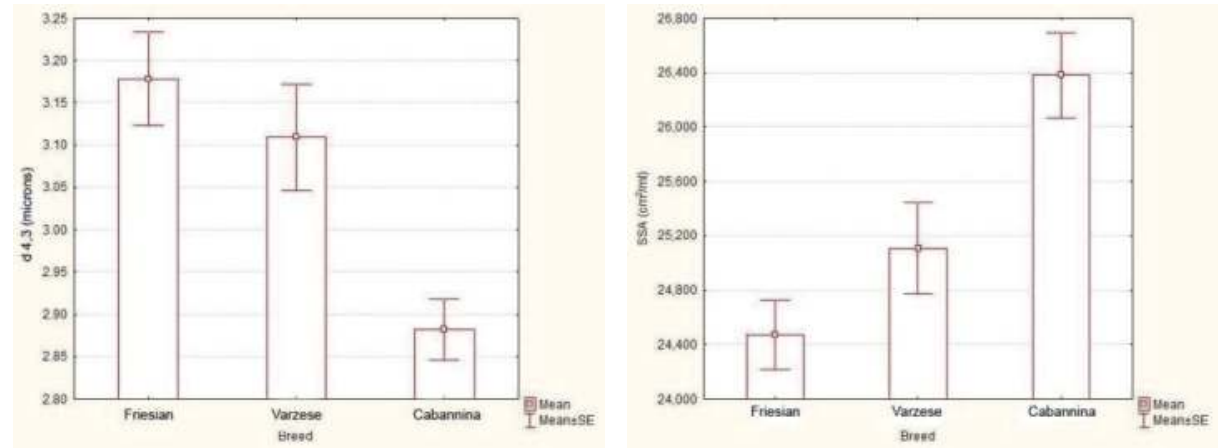

Fig. 7.1. and 7.2. Mean+SE for $\mathrm{d}_{43}$ (volume weighted diameter) and for SSA (Specific Surface Area) in breeds during survey. Differences among groups were statistically significant $(\mathrm{p}<0.05)$.

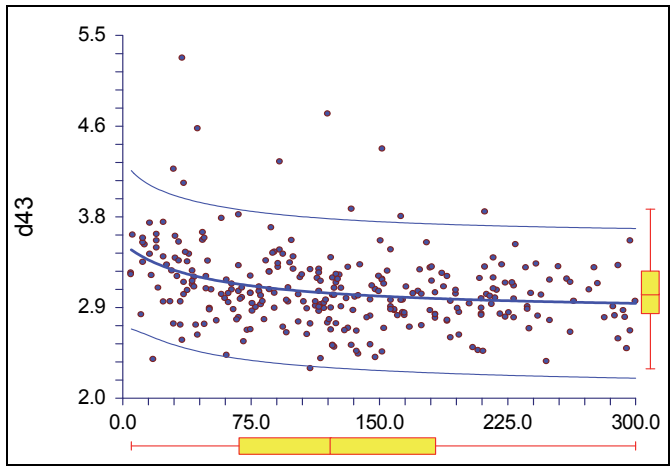

Fig. 7.3. Trend of mean globular diameter d43 during lactation. Regression curve and limits are given after months. 


\subsection{Milk fatty acids profile}

Mean milk production of the three groups of cows during observation period was $14.24 \pm 4.36 \mathrm{~kg}, 24.17 \pm 6.84 \mathrm{~kg}$, and $11.84 \pm 4.59 \mathrm{~kg}$ for the Cabannina, Holstein and Varzese, respectively. Mean productions were significantly different (ANOVA, $\mathrm{p}<0.001$ ), and the three groups were all significantly different when compared pairwise (Tukey test, $\mathrm{p}<0.05$ ). The three breeds showed an overall fat percentage of $4.05 \pm 1.14 \%$ (Cabannina, $\mathrm{n}=36$ ), $3.53 \pm 1.01 \%$ (Holstein, $\mathrm{n}=39$ ) and $4.27 \pm 0.87$ (Varzese, $\mathrm{n}=30$ ). The univariate descriptive statistics for the variables considered are summed up in Table 7.1. Results also report ANCOVA significances for breed and time. At first glance, great differences among groups can be noticed. In particular, the Varzese breed shows higher percentages of C16:1c, C18:1c, $\Sigma$ MUFA, and higher levels in $\Delta 16, \Delta 18$ and $\Sigma \Delta$; Cabannina milk reveals significantly higher levels in $\mathrm{C} 14: 1 c$ and $\Delta 14$, whereas it is in an intermediate position about $\Delta 16$ and $\Delta 18$. Holstein cows maintain the lowest percentages for all the MUFAs determined. Positive significant temporal trends $(\mathrm{p}<0.05)$ were observed for $\mathrm{C} 14: 1 c, \mathrm{C} 16: 1 c$ and for $\Delta 14, \Delta 16, \Delta 18$ and $\Sigma \Delta$. A significant trend for the other variables was not evidenced.

\begin{tabular}{|c|c|c|c|c|c|c|}
\hline \multicolumn{4}{|c|}{ Breed } & \multicolumn{3}{|c|}{ ANCOVA } \\
\hline $\begin{array}{l}\text { Fatty acid } \\
(\%)\end{array}$ & Cabannina & Friesian & Varzese & Breed & $\begin{array}{l}\text { Day of } \\
\text { lactation }\end{array}$ & $\begin{array}{l}\text { Time } \\
\text { trend }\end{array}$ \\
\hline C14:1-cis & $1.14 \pm 0.25^{a}$ & $0.96 \pm 0.32^{b}$ & $1.03 \pm 0.40^{\mathrm{ab}}$ & * & $* * *$ & $\uparrow$ \\
\hline C16:1-cis & $1.93 \pm 0.75$ & $1.80 \pm 0.73$ & $2.13 \pm 0.80$ & n.s. & $* * *$ & $\uparrow$ \\
\hline C18:1-cis & $19.60 \pm 3.64^{b}$ & $16.78 \pm 3.89 c$ & $22.30 \pm 3.81^{a}$ & $* * *$ & n.s. & $=$ \\
\hline$\sum$ cis-MUFA & $22.40 \pm 5.35^{b}$ & $19.91 \pm 4.11^{c}$ & $25.31 \pm 5.27 \mathrm{a}$ & $* * *$ & n.s. & $=$ \\
\hline \multicolumn{7}{|l|}{ Desaturase } \\
\hline$\Delta 14$ & $6.95 \pm 1.44^{\mathrm{a}}$ & $6.06 \pm 2.08^{b}$ & $6.77 \pm 2.63 \mathrm{ab}$ & 0.07 & $* * *$ & $\uparrow$ \\
\hline$\Delta 16$ & $5.15 \pm 1.80 \mathrm{ab}$ & $4.20 \pm 1.72^{b}$ & $5.71 \pm 2.21^{\mathrm{a}}$ & * & * & $\uparrow$ \\
\hline$\Delta 18$ & $67.32 \pm 3.70^{\mathrm{ab}}$ & $65.06 \pm 5.14^{b}$ & $69.85 \pm 5.90^{a}$ & $* *$ & * & $\uparrow$ \\
\hline$\Sigma \Delta$ & $26.58 \pm 4.18^{\mathrm{b}}$ & $23.00 \pm 4.41^{\mathrm{c}}$ & $29.98 \pm 4.05^{\mathrm{a}}$ & $* * *$ & n.s. & $=$ \\
\hline
\end{tabular}

Table 7.1. Univariate descriptive statistics and ANCOVA results for cis-MUFA profiles and desaturase indices in different dairy cow breeds. cis-MUFA = cis-monounsaturated fatty acids - a-cDifferent superscripts indicate a $\mathrm{p}<0.05$ difference (correct $\mathrm{t}$-test for multiple comparisons) $-\stackrel{*}{=} p<0.05 ;{ }^{* *}=p<0.01 ;{ }^{* * *}=p<0.001-\Delta=$ Desaturase Index; $\Sigma \Delta=$ Total Desaturase Indices - n.s. $=$ not significant $-\uparrow=$ increasing time trend $-\downarrow=$ decreasing time trend $-==$ constant time trend.

\subsection{Hydroxyproline}

Preliminary results show some differences from what has been described in Friesian cows: in fact, autochthonous cows show more outstanding curves inclination than Friesian and a shorter timeframe for uterine involution, as they achieve optimal levels (about $12 \mu \mathrm{g} / \mathrm{ml}$ ) already 20 days after birth (Fig. 7.4.). 


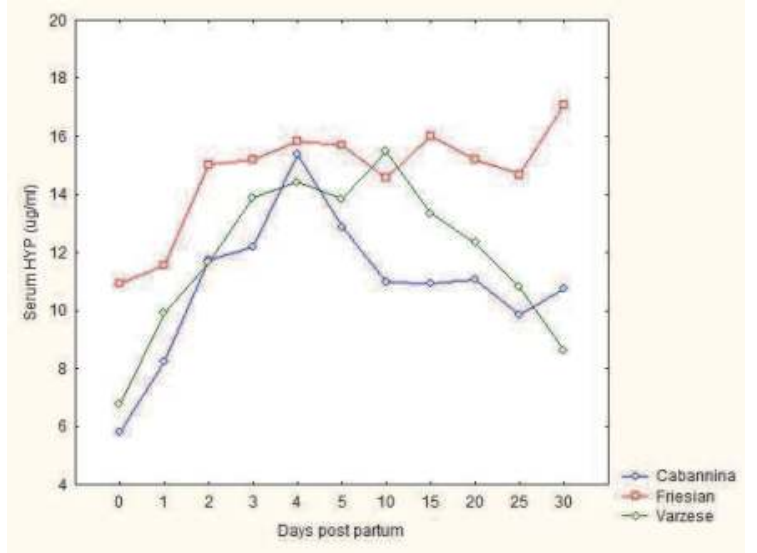

Fig. 7.4. Comparison of serum hydroxyproline content trend in Varzese cows (green), Friesian cows (red) and Cabannina cows (blue) during post partum period.

\section{Discussion and conclusions}

The present investigation highlights important among-breed variations. First of all, variations in milk fat dimension and composition, evidence of milk biodiversity deriving from breed biodiversity. In fact, fat globules are very different in the three breeds we considered; in particular, Cabannina breed has the smallest ones. As described by Lopez et al., 2011 both size and surface area of fat globules are important parameters that can influence the mechanisms of hydrolysis of lipids by digestive enzymes. Smaller globules are better as they present a bigger surface area to enzymes, which increases digestive processes. According to Fauquant et al. (2005), a different composition and size of fat globules could change functional and sensory properties of dairy products. Michalsky et al. in 2007 showed that cheese with small-fat globules exhibited greater stretching and elasticity and improved sensory characteristics. The content in cis-MUFA found in the present research is quite similar to data reported in recent literature (Michalsky et al., 2007; Lopez et al., 2011). Enhancement of cis-MUFA in milk is desirable for human consumption, as reported by Givens (2008): higher intakes of cis-MUFA and a reduction in short fatty acids decrease plasma insulin levels, total plasma cholesterol and LDL-cholesterol concentrations, therefore reducing risks for coronary heart diseases (CHD). A higher intake of cis-MUFA is also wellconsidered in type-2 diabetes, as reported by Ros (2003), that underlines as cis-MUFAs are an alternative to low-fat diets in the management of diabetes. Moreover, Lauszus et al. (2001) indicate that intake of MUFAs may prevent blood pressure from rising in gestational diabetes mellitus, with no influence on lipid and lipoprotein concentrations. In a survey conducted in $11 \mathrm{EU}$ member states, intake of cis-MUFA from dairy products ranges from 8.3 to $28.6 \%$ of total intake of cis-MUFA (Givens, 2008), confirming the huge contribution of milk and dairy products in cis-MUFA intake. The report by Givens suggests that modification of fatty acid content in milk obtained by replacing short fatty acids with cisMUFA may reduce risk for CHD in the population, which implies that European agricultural policies should be deeply changed. Positive effects of cis-MUFA can also be exerted on udder health: during mastitis, for example, an enhancement in lipase activity can 
be appreciated, with the increase of free fatty acids, mainly short chain ones (Randolph and Erwin, 1974); several fatty acids are endowed of a good antibiotic power, that can be expressed via inhibition of enzyme/fatty acid synthesis/nutrient uptake, cell lysis, metabolites leakage, disruption of electron transport chain, interference with oxidative phosphorylation and lipid peroxidation (Desbois and Smith, 2010; Clément et al., 2007). Furthermore, by enhancing the activity of stearoyl CoA desaturase (SCD), the nutritional value of milk would be ameliorated, but the simple up-regulation of its activity seems to be limited, as reported in a comprehensive milk lipid synthesis model (Shorten et al., 2004). In the present research, the local breeds considered show either higher levels in cis-MUFAs or in desaturase indices: features that are likely to be linked to genetics, as evidenced by Schennink et al. (2008), by a complex interaction in gene/allele expressions, and that could be used to improve the nutritional value of milk.

About reproduction physiology, the results obtained indicate that the reproductive physiology of Varzese and Cabannina is characterized by an early resumption of ovarian activity and by an early fecundation opportunity: in fact, the onset of first estrus can be observed 20 days after birth and the opportunity to impregnate can occur in the following cycle, i.e. approximately 40 from birth. That would allow farmers to achieve the goal of a calf/year, as the primary indicator of welfare, reproductive efficiency and good mammary function. According to unpublished data, obtained during trials, it could be said that autochthonous breeds have peculiar features to solve current problems of the scenario of high yielding dairy cows. As previously said, in the current system of cattle breeding, cows have dramatically increased "energy and financial voracity "(diet based on starch and protein meals, great health and structural investments due to several high recurring diseases (Ingvartsen et al., 2003; Collard et al., 2000; Carlén et al., 2004). In post partum period, energy needs required by high-yielding Holstein cows has increased by $25 \%$ compared to thirty years ago, despite the considerably limited growth in muscle masses (Agnew et al., 2003). All experts know about mobilization of various constituents from adipose tissue to support breast functions in producing milk (Veerkamp, 1998), but few know that the muscle is an important structure for reserves of amino acids. In highly selected cows this phenomenon is much more marked than in cows genetically less selected (Pryce 2004). A cow's energy balance decreases even a couple of weeks before parturition, as a result of the animal's reduced ability of food ingestion. In the first weeks after birth, food ingestion cannot compensate the wide adipose tissue mobilization. Therefore, cows maintain this status of negative energy balance (NEB) for 5-7 weeks from birth (Grummer 2007). At the beginning of lactation, mobilization of adipose tissue and low blood glucose bioavailability are key events to induce metabolic syndromes (Ingvartsen et al., 2003), ketosis, liver diseases, paretic-spastic syndromes and foot diseases (Collard et al., 2000). In autochthonous dairy farms ketosis and other metabolic syndromes are hardly ever present: in fact, these cows can keep up their double aptitude for maintaining a good milk production and creating a favorable muscle mass. A feature giving Cabannina and Varzese cows an interesting physiological ability to solve imbalances during NEB status through abundant energy reserves (consisting of subcutaneous and inframisial adipose tissue and muscle itself) immediately available to provide the animals with glucose and amino acids.

In conclusion, restoration of endangered niche breeds can undoubtedly give a boost to local products and to conservation of livestock biodiversity; FAO sustains livestock biodiversity 
as a "safety net for the future", mainly in developing countries, as reported in a recent document, FAO, 2010. These principles can also be extended to developed countries with the aim to better exploit local resources and preserve relic breeds from an impending extinction which would mean the loss of a priceless legacy. In the forthcoming years, the peculiar nutritional and nutraceutical aspects present in milk and in dairy products deriving from biodiversity farms will hopefully show up.

\section{Acknowledgment}

The authors are grateful for animal and sampling supply to Mr. Luigi Antonio Chierico, a precursory breeder in Valle Salimbene, (Pavia, Lombardy), who runs the only and unique bovine biodiversity farm existing in the world.

\section{References}

Ackman, R.G. (2002). The gas chromatograph in practical analyses of common and uncommon fatty acids for the 21st century. Analytica Chimica Acta, Vol.465, No.1-2, (August 2002), pp. 175-192, ISSN 0003-2670

Agnew, R.E.; Yan, T.; Murphy, J.J.; Ferris, C.P. \& Gordon, F.J. .(2003). Development of maintenance requirement and energetic efficiency for lactation from production data of dairy cows. Livestock Production Science, Vol.82, No.(1-2), pp. 151-162, ISSN 1871-1413

Badinand, F. (1993). Involution uterine-physiologie-pathologie. Atti della Società Italiana di Buiatria, Vol XXV, pp. 41-57, ISSN

Banks, W., Clapperton, J. L. \& W. Steele. 1983. Dietary manipulation of the content and fatty acid composition of milk fat. Proceedings of the Nutrition Society. Vol.42, No.3, pp. 399-406, ISSN 0029-6651

Bigi, D. \& Zanon, A. (2008). Atlante delle razze autoctone, Edagricole, ISBN 978-88-506-5259-4, Milano, Italia.

Carlén, E.; Strandberg, E. \& Roth, A. 2004. Genetic Parameters for Clinical Mastitis, Somatic Cell Score, and Production in the First Three Lactations of Swedish Holstein Cows. Journal of Dairy Science, Vol.87, No.9, (September 2004), pp. 3062-3070, ISSN 0022-0302

Chilliard, Y., Ferlay, A.; Mansbridge, R.M. \& Doreau, M. (2000). Ruminant milk fat plasticity: nutritional control of saturated, polyunsaturated, trans and conjugated fatty acids. Annales de Zootechnie, Vol.49, No.3, (November 2000), pp. 181-205, ISSN 0003-424X

Clément, M.; Tremblay, J.; Lange, M.; Thibodeau, J. \& Belhumeur, P. (2007). Whey-derived free fatty acids suppress the germination of Candida albicans in vitro. Fems Yeast Research, Vol.7, No.2, (March 2007), pp. 276-285, ISSN 1567-1356

Collard, B.L.; Boettcher, P.J.; Dekkers, J.C.M.; Petitclerc, D. \& Schaeffer, L.R. (2000). Relationships between energy balance and health traits of dairy cattle in early lactation. Journal of Dairy Science, Vol.83, (May 2000), pp.2683- 2690, ISSN 0022-0302

Desbois, A.P. \& Smith, V.J.. (2010). Antibacterial free fatty acids: activities, mechanisms of action and biotechnological potential. Applied Microbiology and Biotechnology, Vol.85, No.6, pp. 1629-1642, ISSN 1432-0614 
Elliot, K.; McMahon, K.J.; Gier, H.T. \& Marion G.B. (1968). Uterus of the cow after parturition: bacterial content. American Journal of Veterinary Research, Vol.29, pp. 7781, ISSN 0002-9645

Elwood, P.C.; Pickering, J.E.; Givens, D.I. \& Gallacher, J.E. (2010). The consumption of milk and dairy foods and the incidence of vascular disease and diabetes: an overview of the evidence. Lipids, Vol.5, No.10, (March 2010), pp. 925-939, ISSN 1558-9307

Fauquant, C.; Briard, V.; Leconte, N. \& Michalski, MC. (2005). Differently sized native milk fat globules separated by microfiltration: fatty acid composition of the milk fat globule membrane and triglyceride core. You have full text access to this content, European Journal of Lipid Science and Technology, Vol.107, (February 2005), pp.80-86, ISSN 1438-9312

Forcato, D.O.; Carmine, M.P. ; Echeverria, G.E.; Pecora, R.P. \& Kivatinitz, S.C. (2005). Milk fat content measurement by a simple UV spectrophotometric method: An alternative screening method. Journal of Dairy Science, Vol.88, No.2, (February 2005), pp.478-481, ISSN 0022-0302

Givens, D.I. (2008). Session 4: Challenges facing the food industry in innovating for health: impact on CVD risk of modifying milk fat to decrease intake of SFA and increase intake of cis-MUFA, Proceedings of the Nutrition Society, ISSN 0029-6651, Symposium, Dublin, IRAN, REPUBLIQUE ISLAMIQUE (18/06/2008), pp. 419-427

Grummer, R.R. (1990). Effect of feed on the composition of milk fat. Journal of Dairy Science, Vol.73, pp. 88, ISSN 0022-0302

Grummer, R.R. (2007). Strategies to improve fertility of high yielding dairy farms: Management of the dry period. Theriogenology, Vol.S68, pp. S281-S288, ISSN 0093-691X

Hurtgen, J.P. \& Ganiam, V.K. (1979). The effect of intrauterine and cervical manipulation on the equine oestrous cycle and hormone profiles. Journal of Reproduction and Fertility, Vol.27, pp. 191-197, ISSN 0022-4251

Huszar, G.; Maiocco, J. \& Naftolin F. (1980). Monitoring of collagen and collagen fragments in chromatography of protein misture. Analytical Biochemistry, Vol.105, No.1, (June 1980), pp. 424-429, ISSN 0003-2697

Ingvartsen, K.L.; Dewhurst, R.J. \& Friggens, N.C. (2003). On the relationship between lactational performance and health: is it yield or metabolic imbalance that causes diseases in dairy cattle? A position paper. Livestock Production Science, Vol.83, pp. 277-308, ISSN 1871-1413

Kaidi, R.; Brown, P.J.; David, J.S.E.; Etherington, D.J. \& Robins S.P. (1991a). Uterine collagen during involution in cattle. Matrix, Vol.11, pp. 101-107, ISSN 1936-2994

Kaidi, R.; Brown, P.J. \& David, J.S.E. (1991b). Uterine involution in cattle. Veterinary Annual, Vol.31, pp. 39-50, ISSN 0083-5870

Lauszus, F.F.; Rasmussen, O.W.; Henriksen, J.E.; Klebe, J.G.; Jensen, L.; Lauszus, K.S. \& Hermansen, K. (2001). Effect of a high monounsaturated fatty acid diet on blood pressure and glucose metabolism in women with gestational diabetes mellitus. European Journal of Clinical Nutrition, Vol.55, No.6, (June 2001), pp. 436-443, ISSN 0954-3007

Lopez, C. (2005). Focus on the supramolecular structure of milk fat in dairy products. Reproduction Nutrition Development, Vol.45, No.4, (July-August 2005), pp. 497-511, ISSN 0926-5287 
Lopez, C.; Briard-Bion, V.; Ménard, O.; Beaucher, E.; Rousseau, F.; Fauquant, J.; Leconte, N. \& Robert, B. (2011). Fat globules selected from whole milk according to their size: different compositions and structure of the biomembrane, revealing sphingomyelin-rich domains. Food Chemistry, Vol.125, No.2, (March 2011), pp. 355368, ISSN 0308-8146

Manirakiza, P.; Covaci, A. \& Schepens, P. (2001). Comparative study on total lipid determination using Soxhlet, Roese-Gottlieb, bligh \& dyer, and modified bligh \& dyer extraction methods. Journal of Food Composition and Analysis, Vol.14, No.1, (February 2001), pp. 93-100, ISSN 1096-0481

Mele, M.; Conte, G.; Castiglioni, B.; Chessa, S.; Macciotta, N.P.P.; Serra A.; Buccioni, A.; Pagnacco, G. \& Secchiari, P. (2007). Stearoyl-Coenzyme A desaturase gene polymorphism and milk fatty acid composition in Italian Holsteins. Journal of Dairy Science, Vol.90,No.9, (September 2007), pp. 4458-4465, ISSN 0022-0302

Michalski, M.; Gassi, J.Y.; Famelart, M.H.; Leconte, N.; Camier, B.; Michel, F. \& Briard, V. (2003). The size of native milk fat globules affects physical-chemical and sensory properties of Camembert cheese. Dairy Science and Technology. Le Lait, Vol.83, No.2 (June 2003), pp.131-143, ISSN 1958-5594

Michalski, M.C.; Ollivon, M.; Briard, V.; Leconte, N. \& Lopez, C. (2004). Native fat globules of different sizes selected from raw milk: thermal and structural behaviour. Chemistry and Physics of Lipids, Vol.132, No.2, (December 2004), pp. 247-261, ISSN 0009-3084

Michalski, M.C.; Camier, B.; Gassi, J.Y.; Briard-Bion, V.; Leconte, N.; Famelart, M.H. \& Lopez, C. (2007). Functionality of smaller vs control native milk fat globules in Emmental cheeses manufactured with adapted technologies. Food Research International, Vol.40, No.1, (January 2007), pp. 191-202, ISSN 0963-9969

Molto-Puigmarti, C.; Castellote, A.I. \& Lopez-Sabater, M.C. (2007). Conjugated linoleic acid determination in human milk by fast-gas chromatography. Analytica Chimica Acta, Vol.602, No.1, pp. 122-130, ISSN 0003-2670

Pereira, S.L.;. Leonard, A.E. \& Mukerji, P. (2003). Recent advances in the study of fatty acid desaturases from animals and lower eukaryotes. Prostaglandins Leukotrienes and Essential Fatty Acids, Vol.68, No.2, (February 2003), pp. 97-106, ISSN 1098-8823

Perfield, J.W. II; Delmonte, P.; Lock, A.L.; Yurawecz, M.P. \& Bauman, D.E. (2006). Trans-10, trans-12 conjugated linoleic acid does not affect milk fat yield but reduces $\Delta 9$ desaturase index in dairy cows. Journal of Dairy Science, Vol.89, No.7, (July 2006), pp. 2559-2566, ISSN 0022-0302

Perfield, J.W. II; Lock, A.L.; Griinari, J.M.; Sab, A.; Delmonte, P.; Dwyer, D.A. \& Bauman, D.E. (2007). Trans-9, Cis-11 conjugated linoleic acid reduces milk fat synthesis in lactating dairy cows. Journal of Dairy Science, Vol.90, No.5, (May 2007), pp. 22112218, ISSN 0022-0302

Pryce, J.E., Royal, M.D.; Garnsworthy, P.C. \& Mao, I.L. (2004). Fertility in the highproducing dairy cow. Livestock Production Science, Vol.86, No.1-3, (March 2004), pp. 125-135, ISSN 1871-1413

Randolph, H.E. \& Erwin, R.E. (1974). Influence of mastitis on properties of milk.10. Fattyacid composition. Journal of Dairy Science, Vol.57, No.8, (August 1974), pp. 865-868, ISSN 0022-0302 
Ros, E. (2003). Dietary cis-monounsaturated fatty acids and metabolic control in type 2 diabetes. The American Journal of Clinical Nutrition, Vol.78, No.3suppl, (September 2003), pp. 617S-625S, ISSN 1938-3207

Rosenberger, G. (1979). L'esame clinico del bovino, Ed. Essegivi, Edagricole, ISBN 88-206-37138, Piacenza, Italy

Roxström, A.; Strandberg, E.; Berglund, B.; Emanuelson, U. \& Philipsson, J. (2001a). Genetic and environmental correlations among female fertility traits and milk production in different parities of Swedish Red and White dairy cattle. Acta Agriculturae Scandinavica, Section A - Animal Science, Vol.51, No.1, pp.7-14, ISSN 0906-4702

Roxström, A.; Strandberg, E.; Berglund, B.; Emanuelson, U. \& Philipsson, J. (2001b). Genetic and environmental correlations among female fertility traits and the ability to show oestrus, and milk production. Acta Agriculturae Scandinavica, Section A - Animal Science, Vol.51, No.3, pp. 192-199, ISSN 0906-4702

Sandri, S.; Summer, A.; Tosi, F.; Mariani, M.S.; Pecorari, M.; Franceschi, P.; Formaggioni, P.; Pederzani, D. \& Malacarne, M. (2010). Influence of somatic cell content on dairy aptitude of milk. Scienza e Tecnica Lattiero-Casearia, Vol.61, No.1, pp. 5-18, ISSN 0390-637X

Schennink, A.; Stoop, W.M.; Visker, M.H.P.W.; Heck, J.M.L.; Bovenhuis, H.; Poel, J.J.v.d.; Valenberg, H.J.F.v. \& Arendonk, J.A.M.v. (2007). DGAT1 underlies large genetic variation in milk-fat composition of dairy cows. Animal Genetics, Vol.38, No.5, (October 2007), pp. 467-473, ISSN: 1365-2052

Schennink, A.; Heck, J.M.L.; Bovenhuis, H.; Visker, M.H.P.W.; Valenberg, H.J.F.v. \& Arendonk, J.A.M.v. (2008). Milk fatty acid unsaturation: genetic parameters and effects of Stearoyl-CoA desaturase (SCD1) and Acyl CoA: diacylglycerol acyltransferase 1 (DGAT1). Journal of Dairy Science, Vol.91, No.5, (May 2008), pp. 2135-2143, ISSN 0022-0302

Shorten, P.R.; Pleasants, T.B. \& Upreti, G.C. (2004). A mathematical model for mammary fatty acid synthesis and triglyceride assembly: the role of stearoyl CoA desaturase (SCD). Journal of Dairy Research, Vol.71, No.4, pp. 385-397, ISSN 0022-0299

Sørensen, A.C.; Lawlor, T. \& Ruiz, F. (2007). A survey on fertility in the Holstein populations of the world. In: Proceedings of the Int Conf on Fertility in dairy cows "EAAP Satellite Meeting", pp. 1:17, ISBN 91-576-5678-9, Liverpool Hope University, UK, 30-31 August 2007

Soyeurt, H.; Dardenne, P.; Gillon, A.; Croquet, Vanderick, C.S.; Mayeres, P.; Bertozzi, C. \& Gengler, N. (2006). Variation in fatty acid contents of milk and milk fat within and across breeds. Journal of Dairy Science, Vol.89, No.12, (December 2006), pp. 48584865, ISSN 0022-0302

Soyeurt, H.; Gillon, A.; Vanderick, S., Mayeres, P.; Bertozzi, C. \& Gengler, N. (2007). Estimation of heritability and genetic correlations for the major fatty acids in bovine milk. Journal of Dairy Science, Vol.90, No.9, (September 2007), pp. 4435-4442, ISSN 0022-0302

Soyeurt, H.; Dehareng, F.; Mayeres, P.; Bertozzi, C. \& Gengler, N. (2008). Variation of $\Delta 9$ desaturase activity in dairy cattle. Journal of Dairy Science, Vol.91, No.8, (August 2008), pp. 3211-3224, ISSN 0022-0302 
Veerkamp, R.F. (1998). Selection for economic efficiency of dairy cows using information on live weight and feed intake: A review. Journal of Dairy Science, Vol.81, No.(4), pp. 1109-1119, ISSN 0022-0302

Vessby, B. (2003). Dietary fat, fatty acid composition in plasma and the metabolic syndrome. Current Opinion in Lipidology, Vol.14, No.1, (February 2003), pp.15-19, ISSN 14736535 




\author{
Food Production - Approaches, Challenges and Tasks \\ Edited by Prof. Anna Aladjadjiyan
}

ISBN 978-953-307-887-8

Hard cover, 270 pages

Publisher InTech

Published online 20, January, 2012

Published in print edition January, 2012

This book is devoted to food production and the problems associated with the satisfaction of food needs in different parts of the world. The emerging food crisis calls for development of sustainable food production, and the quality and safety of the food produced should be guaranteed. The book contains thirteen chapters and is divided into two sections. The first section is related to social issues rising from food insufficiency in the third world countries, and is titled "Sustainable food production: Case studies". The case studies of semi-arid Africa, Caribbean and Jamaica, Burkina Faso, Nigeria, Pacific Islands, Mexico and Brazil are discussed. The second section, titled "Scientific Methods for Improving Food Quality and Safety", covers the methods for control and avoidance of food contaminants. Substitution of chemical treatment with physical, rapid analytical methods for control of contaminants, problems in animal husbandry related to diary production and hormones in food producing animals, approaches and tasks in maize and rice production are in the covered by 6 chapters in this section.

\title{
How to reference
}

In order to correctly reference this scholarly work, feel free to copy and paste the following:

Ricardo Communod, Massimo Faustini, Luca Maria Chiesa, Maria Luisa Torre, Mario Lazzati and Daniele Vigo (2012). ChaMilk Biodiversity: Future Perspectives of Milk and Dairy Products from Autochthonous Dairy Cows Reared in Northern Italy, Food Production - Approaches, Challenges and Tasks, Prof. Anna Aladjadjiyan (Ed.), ISBN: 978-953-307-887-8, InTech, Available from: http://www.intechopen.com/books/food-productionapproaches-challenges-and-tasks/milk-biodiversity-future-perspectives-of-milk-and-dairy-products-fromautochthonous-dairy-cows-reare

\section{INTECH}

open science | open minds

\section{InTech Europe}

University Campus STeP Ri

Slavka Krautzeka 83/A

51000 Rijeka, Croatia

Phone: +385 (51) 770447

Fax: +385 (51) 686166

www.intechopen.com

\section{InTech China}

Unit 405, Office Block, Hotel Equatorial Shanghai

No.65, Yan An Road (West), Shanghai, 200040, China 中国上海市延安西路65号上海国际贵都大饭店办公楼 405 单元

Phone: +86-21-62489820

Fax: +86-21-62489821 
(C) 2012 The Author(s). Licensee IntechOpen. This is an open access article distributed under the terms of the Creative Commons Attribution 3.0 License, which permits unrestricted use, distribution, and reproduction in any medium, provided the original work is properly cited. 